\title{
Characteristics of Owner-Managers of Cameroonian Family SMEs and Access to Bank Credit
}

\author{
Samuel Roland MAKANI \\ Ph.D Student in Management Science, Department of Accounting and Finance, Faculty of Economics and \\ Management, Research Laboratory in Management (LAREMA) University of Dschang, Cameroon \\ Nestor Magloire LETSINA \\ Ph.D Student in Management Science, Department of Accounting and Finance, Faculty of Economics and \\ Management, Research Laboratory in Management (LAREMA) University of Dschang, Cameroon \\ Sorielle Cybele EWANE \\ Ph.D Student in Management Science, Department of Accounting and Finance, Faculty of Economics and \\ Management, Research Laboratory in Management (LAREMA) University of Dschang, Cameroon
}

\begin{abstract}
The objective of this paper was to highlight the effect of the characteristics of owner-Cameroonian family SMEs on access to bank credit. To achieve this, we used primary data collected from 180 family SMEs. At the end of the chi-square test and logistic regression, we obtained the following results: The level of education and type of ownermanager training have a significant and negative influence on access to bank credit family SMEs, experience and the geographical origin of the owner-manager and have a significant positive impact on access to bank credit for SMEs family in Cameroon.
\end{abstract}

Keywords: Owner-manager profile, family business, educational level, type of training, Global Home

DOI: $10.7176 /$ RJFA/11-12-02

Publication date:June 30th 2020

\section{Introduction}

Studies in sociology, strategic management, entrepreneurship, organizational behavior, among others, have provided information on family businesses, showing their superiority in terms of economic performance, financial performance, social and even environmental. Regarding the definition of domestic SMEs, researchers adopt a dual approach to define this category of companies. According approachTagiuri and Davis (1982), based on qualitative criteria in terms of involvement and influence on management, family businessis an organization where two or more members of the same extended family influence the management of the company through the exercise of kinship, management positions or ownership rights in the capital. For Hollandler and Elman (1988) Handler (1989), the family business is the one that is owned, managed or controlled by one or more families. Like other businesses, they are facing serious problems of development and funding for their survival.

The funding problem family businesses, both developed and developing countries remains unresolved to this day. Since thework Modigliani and Miller (1958), this problem remains until today valid in all countries of the world. Wamba (2013) found that this phenomenon is more pronounced in developing countries where the SME is a source of job creation, facing serious liquidity shortages, and a great difficulty in accessing Bank financing that impedes their development.

According to the report of the Organization for Economic Cooperation and Development (OECD) in 2015, access to finance, especially bank remains ambiguous and uncertain. He said that the rejection rate linked to the constraints of access to credit, are a concern that affects more SMEs than large companies. The OECD report (2015) advocates the diversification of sources of funding to SMEs, to better meet their needs. It also states that they play a vital role in job creation, especially in developing countries.

In a context like that of Africa in general and Cameroon in particular, we see that many companies face enormous difficulties to finance themselves and in obtaining financing from banking structures. These facts have led in recent years researchers suchthat Bekolo-Ebe (1992, 2002); Nkakleu, (2003); Ndeffo and Ningaye (2007); Wanda (2007); Feudjo and Tchankam, (2012); Wamba (2013), among others, and the Government of Cameroon (MINPMEESA $^{1}$ ) To think about the new mechanisms to bring structures (banks), which, however, remain onliquids, to trust local businesses and finance their growth.

Cameroonian companies operate, according to the INS / EGR-12 (2009), in an unfavorable business environment constituted by obstacles such as taxation (58.8\%), access to credit (37.6\%), paperwork (35.2\%),

\footnotetext{
${ }^{1}$ Ministry of Small and Medium Enterprises of the Social Economy and Crafts.

${ }^{2}$ First General Census of Enterprises conducted by the National Institute of Statistics.
} 
unfair competition (25.8\%) and credit financing costs (18\%). Also according to the INS / EGR-2 ${ }^{1}$ (2018), these companies face obstacles such as taxation 53.5\%, access to financing (30.7\%), paperwork (34.2\%).

Thehe results of the survey conducted by theMINPMEESA (2009) and $\mathrm{JICA}^{2}$ indicate that about $77.1 \%$ of Cameroonian SMEs experiencing funding problems banking. COBAC (2010)notes that between January 2009 and April 2010, no Cameroonian bank could give a long-term business credit than 5\% and in particular SMEs. Wanda (2007) and Fouda (2009) note that despite the fact that credit institutions are in a stategeneral excess liquidity, banks do not always give credit requested by the companies following the restructuring of the Cameroonian banking sector initiated in the late 1980s.

Despite all these difficulties which face Cameroon and family especially SMEs operating in the three traditional sectors (primary, secondary and tertiary sectors), they respectively contributed by the International Monetary Fund (IMF), April 2011), to $29.7 \%, 21.6 \%$ and $48.7 \%$ of GDP. While growth depended heavily ${ }^{3}$ the oil industry in the 80 s, today is the services sector which contributes most strongly (French Development Agency (AFD), 2012).

It is therefore necessary for SMEs to have the right profile that could allow them to attract banks and get bank credit agreements to increase the contribution to GDP and to the development of the economy. Several internal factors ${ }^{4}$ SMEs have been qualified by the empirical work as determinants of access to bank financing, which largely increase the probability of access to conventional credit. The studies that have been developed in this area by several researchers as Levratto (1990); Colot and al. (2010); Kut and Smolarski (2011); Miloudi and Benkraiem (2014), among others, have tried to better understand the problem and

the difficulty of access to bank financing and identify appropriate solutions, based on internal factors of SMEs.

In the same vein, Taka (2016), thinkholding a formal accounting or of Statistics and Tax Statement (STS), the availability of collateral, the debt ratio, size of business, success in the use of ICT, gender of the entrepreneur, positively and significantly influence the probability of obtaining bank financing of SMEs.

Studies conducted by the above mentioned authors and others have proposed solutions, used in ways that can improve access to credit for SMEs and determined the factors that influence their access to finance. But strong is clear that in Cameroon, nothing is done in SMEs or to change or to improve their access to credit whether in practice $^{5}$ in business or in the behavior of business owners and executives.

This behavior of owners and managers of SMEs and especially Cameroonian family raises questions about their ability to understand the level of change that the world is facing; on their ability to understand the standards, laws, regulations and apply them well, especially in accounting. For as well emphasizes Napier (2006), accounting has changed, is changing and will change, so it is necessary to understand the accounting practice under the constant change that firms face. But only we believe that a good understanding of practices can only be achieved by a good study and good learning. This then raises the question:

The aim of this paper is to highlight the characteristics of the owner-managers of SMEs Cameroonian family that can facilitate or cause of their problems of access to bank credit. This objective will allow us to check if the level of education, type of training, experience and the geographical origin of owner-managers of SMEs Cameroonian family influence access to bank credit. We will, at first present a review of the literature, secondly a methodological approach and finally we will present the results and conclusion.

\section{REVIEW OF LITERATURE}

The literature review allows us to have a clearer idea of the concepts that form our research topic from the contribution of other researchers on the subject. It is organized around two points, namely: access to external finance and the cost of financing, the theoretical approach and the formulation of hypotheses.

\subsection{Access to external finance and financing costs}

In a permanent failure context of bank financing, a virtual absence of support structures, a poverty of capital and above all a failure of a relentless and efficient financial market caused by poor quality of accounting and financial information, companies will always be exposed to credit problems. Access to finance is indeed essential to help businesses grow their business, develop new products and to invest in new production sites has become a major obstacle with the main corollary the quality of accounting and financial data.

\subsubsection{Access to finance growth and business development}

Companies to develop must have access to financing. But according De Serres and al. (2006), they need to finance

\footnotetext{
${ }^{1}$ Second General Census of Enterprises conducted by the National Institute of Statistics.

${ }^{2}$ Japan International Cooperation Agency.

${ }^{3}$ According to the OECD (2003), the Cameroonian oil sector accounted for $20 \%$ of GDP in value in the early 1980 s.

4 Good accounting, transparency of information, composition of the management team among others.

${ }^{5}$ These are the practices of the principal accountant source of production of financial information, decision-making basis of financial institutions and tax practices.
} 
their access to financial marketsrs developed to perform effectively and invest. So the point of viewKing and Levine (1993), the development of financial markets would lead to an acceleration of productivity growth and outputs. Using data from the World Bank Enterprise Surveys (WBES) ${ }^{1}$ Beck and al (2005) show that financial problems at the example of the high interest rates and lack of funds in the banking system, significantly reduce the corporate growth.

Ayyagari and al. (2006) show, using survey data conducted between 1999 and 2000 in 80 developed and developing worldwide as the shortcomings of the financial system are the most important obstacles that directly affect business growth. Nkurunziza (2010), found that companies have access to credit are growing faster than those who did not. Ojah and al. (2010), for their part have, in analyzing the survey data conducted among companies in the countries of the East African Community provide evidence according to which internal and external financing channels improve business decision to invest in fixed capital.

Aterido and al. (2007), based on data from the WBES, they confirm that low access to various forms of financing reduces the growth of businesses, especially micro-enterprises and small businesses. By a study of 44 countries and 36 industries in the manufacturing sector, Beck and al. (2006) show that financial development stimulates more growth of small industrial companies than large companies.

The World Bank (2004), for its part states that small businesses often do not have access to formal credit, that is to say the credits provided by the financial markets and rely heavily on internal funds. Bigsten and al. (2003), studying market participation in corporate credit in targeted African countriesThey found that nearly two-thirds of small businesses have credit constraints, while only $10 \%$ of large companies face the same problem. However, there are no such facts which constitute obstacles to the development and growth of businesses and SMEs in particular.

1.1.2. Access to financing and legal system

Some authors such as Beck, Demirguc-Kunt and Levine (2004), establish a relationship between the legal system and access to finance. Indeed, using data from a survey conducted on companies encountering financing problems, they found that the legal system of a country is an important factor to explain the business difficulties in obtaining external financing.

In the same vein, Beck and al. (2005) study the impact of corruption, access to finance and judiciary enterprises on the level offinancial development, legal and corruption in 54 countries. The results they arrive indicate that countries where there is less corruption and better financial and legal systems, business growth is less affected and that it is the small businesses that are more beneficial as they are the most affected by these barriers.

1.1.3. The cost of funding

Ayyagari and al. (2008) find that, besides the fact that companies face many specific funding problems, for example, lack of access to long term capital and collateral requirements, only the cost of borrowing directly affects business growth. Beck and al. (2006) analyze the determinants of financial barriers. They discover that twelve funding constraints, more than half of companies report topped the list rates.

As for the cost of financing high interest followed by lack of access to long-term loans as major obstacles to growth.

1.1.4. Access to finance, transparency and quality of financial information

The reluctance and fear of banks towards SMEs are mainly due to the strong asymmetric information between entrepreneurs and bankers. Several factors specific to the context of Central Africa and Cameroon in particular, are at the origin of this situation. First, asemphasizes Kauffmann (2005) and the IMF (2006a), the absence of accounting rules or rather the excessive level of accounting information required in the case of Central Africa by the OHADA standards ${ }^{2}$ as well as the lack of independent, competent and credible accounting firms have an impact on the quality of financial information provided to banks.

Moreover, in SMEs, borders are often poorly established between corporate assets and contractor's personal wealth, personal and business credit credit, making it more difficult for the banker to assess repayment capacity of loans to borrowers. Moreover, entrepreneurs may have an interest to broadcast a very limited financial information or even wrong, to escape taxation (pay less tax) and access to credit requested. In this sense, The Cameroonian enterprises are characterized by the production of very biased accounting, often justified by the observation in companies establishing more financial statements for the needs of a cause or to achieve a specific goal (Ndjanyou 2001 ; Ananga and Makani, 2018). To this end, there are a tax balance sheet with poor situation of the company (therefore a low amount of tax support), balance sheet with a positive net worth for the specific purpose of seeking funding from banks and donors funds and finally a realistic assessment informing the owner or owners on the actual health of the company and held by them.

This is largely observed in Cameroon, where individual mostly SMEs and representing $99.8 \%$ according to INS / EGR-2 (2018), have according to (IMF, 2006b), a great ability to manipulate the financial statements and to

\footnotetext{
${ }^{1}$ Database of surveys of private sector enterprises in the economy from representative samples: http://www.enterprisesurveys.org/About-Us.

${ }^{2}$ Organization for Harmonization in Africa of Business Law.
} 
move into the informal sector to escape the fiscal pressures. The example of Cameroon is particularly ${ }^{1}$. There is often no tools enabling banks to know the payment behavior of their new customers and risks associated with loans granted to them. Credit bureaus or central payment incidents are either absent or obsolete.

In this context, informal communication between the bank and the entrepreneur has to offset the deficiency of conventional communication channels. The reputation of the contractor and its proximity to the banker (kinship, neighborly relations, member of the same association of the same religious congregation, a national of the same village and others) are elements at least as important as quality releases financial statements to the bank to facilitate access to credit.

1.2. The agency relationship and access to bank credit

The contractual theory of the firm Jensen and Meckling (1976), consider two agency relationships: the relationship between managers and shareholders and the relationship between the firm and creditors. In both the second single framework for relations with our work in the context of Cameroon, according the EGR-2 (2018), 89\% of companies are directed by their promoter. Thus, in their financing needs, these SMEs maintain relationships with banks, relationships in which the absence of the leaders made sure that business owners are replacing agent and behave as she. These relationships between companies and banks usually give birth to informational asymmetries between the parties. Therefore the role of the governance system is to secure the profitability of financial investment and reduce agency costs born of conflicts between parties(Shleifer and Vishny, 1997).

The costs generated by such situations are losing value against an ideal situation where there will be no information asymmetry and conflict of interest. For the agency theory, an organization is deemed effective if it reduces agency costs. According to Jensen and Meckling (1976), agency problems create three types of costs:

- Monitoring costs: these are costs incurred by the principal to ensure that his agent operates in accordance with its interests;

- obligation costs borne by the agent to the main trust;

- The residual losses: these are costs associated with the divergence of interests between manager and owner (misallocation of resources, choosing a non-optimal strategy ...).

We can also note here, without being puffed sound pretentious or a limit of this theory. In the specific case of Cameroon, we believe that this theory really has no place for two reasons:

- It is a theory built and developed in a managerial context where business leaders do not even know the owners of the company in which they work.

- In Cameroon most of the companies are individual and $99.8 \% 89 \%$ of these companies are run by their owners.

Nevertheless, the problem of covering the agency makes any contractual relationship between individuals, it occurs when the interests of two parties differ and where there is imperfect information, as to the state of nature and the behavior of individuals, and an information asymmetry between the parties. There is also talk of opportunism on the part of either party. For Charreaux (1997), the opportunism of the leaders can speak only if they have a discretion, that is to say if disciplinary mechanisms are imperfectly as suggested by the existence of some seemingly opposite phenomena in the interest of the owners, excessive consumption of non-monetary benefits, costly diversification,

1.3. Characteristic of the owner-manager and training of assumptions

The literature on the characteristics of the owner-manager often distinguishes two groups of elements: the personal characteristics and attitudes. Robidoux (1973) in his study differs in ambient conditions for moral and temperamental nature. Under ambient conditions, the author class family background, rank in the family, heredity, the influence of parents, education level, age, experience and para professional activities; soas part of the conditions of moral and temperamental order, it determines the performance needs, Power, affiliation, risk appetite, flair, self-confidence and innate sense of organization. Toulouse (1979), they exist sociological characteristics such as ethnicity, religion, family background, education, age, work experience and psychological characteristics, that is to say the the attitude of the individual towards risk, which can be a risk to his career, his family, the image he has of himself and of course a monetary risk.

Since early answers to the research question, they channel our work. For this part of the work they are six in number.

1.3.1. The level of education of the owner-manager

An analysis of JICA emphasizes the low level of education that characterizes the employees of Cameroonian SMEs. A little more than one employee in two (61.5\%) did not pass the first cycle of secondary education; Also $9.2 \%$ of employees have never been to school. This is according Nguena (2012), characterized by low levels of

\footnotetext{
${ }^{1}$ According to the GICAM (Cameroonian inter-employer organization), each businessman would spend an average of 4 hours per day in Cameroon with tax administrations.
} 
education negatively affects the financial situation of the company since employees sometimes the uneducated promoter consider the bank as a place reserved for special people where they can not be considered; Even if they have the courage to access it, the lengthy administrative procedures, long queues and many other elements takes them quickly to change his mind. This allows us to hypothesize a following:

\section{H1: The higher the level of education of the owner-manager, the more it has access to bank credit.}

1.3.2. The type of training the owner-manager

According to McMahon and al. (1993), the leader who have received training in management is able to analyze and interpret financial statements, which according to bankers is positive because it allows him to reduce the financial risk. According to these authors, the level of bank debt of SMEs run by managers is higher than that of SMEs run by non-managers. In addition, St-Pierre (2004), believes that knowledge of the leader of the SME is a source of performance. According to this author, the leader with knowledge management is able to perform financial controls and reducing the company's bankruptcy risk. This knowledge managementcan then flatter or seduce the banker. In addition, knowing the behavior of bank financing including tax savings it provides, the manager leader can be brought more to use bank debt. This literature review shows that the executive management training has a positive influence on the level of bank loans to SMEs. From this stems the following hypothesis:

\section{H2: The type of owner-manager training significantly affects access to bank credit.}

\subsubsection{The experience of the owner-manager and access to external financing}

Like education, the quality of training and the origin, the type of experience the owner-manager is another important variable noted by the authors in the literature.

The study of this variable is also approached from two different angles, one hand, there is research devoted to the study of factors such as dissatisfaction, the projection and the advent of new living conditions which are likely to push the owner-manager to go into business. These are situations that have little contact with the career path of the entrepreneur because it is somehow forced to take the decision to go into business without this decision was the result of a long reflection and decision reasonably.

The importance of experience does evident not only in the company's performance. It may also appear at the launch of the company. According to Cooper (1970) it is indeed easy to start a business a second time, regarding decision making and knowledge on how to start and operate a business.

Susbaurer (1972), reports from his study that $90 \%$ of companies have a founder who worked in the same industry; while Cooper (1973), notes that some $85 \%$ of new companies had initial products or services resulting from the prior art experience of the founder. Similarly, Koontz and O'Donnell (1980), indicate that the experience in previous jobs can have an indirect influence on the success of the company. The lessons and the fundamental reasons for successes and past failures serve as useful reference base. More experienced leader is, the more it puts in place mechanisms to protect the company against the risks of too much financial pressure (Teyssier, 2010).

Gasse (1982), said meanwhile that the relative importance of experience on performance seems to be related to the technological complexity and size of business. The same author, the net effect of prior experience on the company's performance depends on personal characteristicsthe contractor and the transmissibility of experience to the new job.

The qualities and important features of the above-mentioned experience may seem like a positive signal in the eyes of bankers since the experience of the owner-manager may allow the company to avoid financial risks, and to increase improve the production of the company and its financial performance thus making liquid and able to honor its commitments. This brings us thus to formulate the following hypothesis:

\section{H3: As the owner-manager is experienced, plus it has access to bank credit.}

\subsubsection{The geographical origin ${ }^{1}$ the owner-manager}

The variable geographical origin is a characteristic feature of social networks. Because networks are built primarily on the basis of family and geographical ties, on ethnicity, religion or social class, among others.

Speaking of social networks and relationships, several authors such as Coleman (1988), Karpik (1989), Baker (1990), Nahapiet \& Ghoshal (1998), have shown that the quality of the social relationship between an economic agent and its environment socioeconomic affect its success. Based on the concept of embedding, Granovetter (1973) studied the impact of social networks on the economic activities of individuals and economic agents.Leaning on the principle of mutual understanding established between the different members of the network, this seems to allow the reduction of information asymmetry problems related to trade.

Lehmann and Neuberger (2001), justified the idea that the loan relationship depends not only transactionsBut also the interaction between partners. Indeed, they showed that the availability and terms of loans (interest rates and demand guarantees) are not only influenced by the characteristics of the company and the variables related to credit risk, but also by interactions social between bankers and executives. Social interactions can indicate the level of trust between the banker and the leader. Nevertheless, this study is a bit limited in the sense that the social dimension of a loan relationship seems too complex to be captured by the variables used by the authors.

\footnotetext{
${ }^{1}$ Corresponds to one of the characteristics of the social network.
} 
Aware of the limitations and the lack of instrumental methods in the evaluation of the uncertainty associated with bank loans, banks have modified their work organization and their management practices to facilitate the emergence of a new social evaluation based on actual social networks used by bankers to establish trust and accumulate social capital may reduce this opacity.

\section{H4: The geographical origin of the owner-manager has a significant impact on access to bank credit.}

\section{METHODOLOGICAL APPROACH}

Scientific research is the main action of production of scientific knowledge. She is also the knowledge production activity highlighting the true state of the world in a particular subject area. To the knowledge produced is accepted as scientific, it must choose an appropriate methodology that would enable to obtain reliable results that can be generalized.

The methodology can be defined as the set of processes, methods or rules that allow a researcher to identify the tools for his research. One can also say that it is the canvas followed by a researcher and allowing it to judge the quality of its research. The methodology is based fundamentally on how to select the search method, choose the method and data collection tools, appropriate statistical tools and software to analyze appropriate data.

Being a view to try to explain the different causes of non-access to external financing of small family businesses from the profile owners, we will proceed to purely empirical research and we have adopted for this reason the quantitative methodology.

2.1. Justification for the choice of the quantitative method The rationale for our approach involves two elements:

\section{- Type of data}

The data in this section are quantitative or numerical. Therefore many authors distinguish the quantitative data with qualitative data. In terms of our work and of our approach, Yin (1989), argues that "digital data" provide evidence of a quantitative nature, while "non-digital data" provide evidence of a qualitative nature. Evrad and al. (2000), quantitative data are collected with intervals of scale and proportion. However, it should be noted that the nature of the data does not necessarily dictate the approach to use. We must therefore evaluate other criteria.

- The objective character

Primarily, the quantitative approach offers greater guarantee of objectivity, this due to the rigor and precision requirements that characterize statistical techniques. The quantitative approach is therefore rooted in the positivist paradigm. according toGrawitz $(1993)^{1}$ the objective nature of the results is a line between qualitative approach andQuantitative pproach. The existence of an objective reality based on the quantitative approach.

\subsection{The nature of the data}

We worked with primary data. The method of collecting primary data in the most developed quantitative research is the questionnaire we used, has the advantage for the researcher to confront directly the persons holding the information. The sample was purposive because of the quality and type of business of the study. Specifically through the feature that the owner or an owner must simultaneously eat. At the end of our investigation, which focused on the Cameroonian family SMEs, 180 questionnaires were selected for use in our work. The 180 questionnaires selected from the surveys conducted in 04 regions of Cameroon as shown in Table 1 below.

\section{Table 1: presentation of the study sample}

\begin{tabular}{|l|l|l|}
\hline Regions & Number & percentage\% \\
\hline Center & 50 & $27.78 \%$ \\
\hline Littoral & 70 & $38.89 \%$ \\
\hline Where is & 40 & $22.22 \%$ \\
\hline South & 20 & $11.11 \%$ \\
\hline Total & $\mathbf{1 8 0}$ & $\mathbf{1 0 0 \%}$ \\
\hline
\end{tabular}

Source: Authors

\footnotetext{
${ }^{1}$ Quoted by Thietar R.A. and Coll (2007), Methods of research in management. 3rd edition, Dunod, Paris, 2007.
} 


\subsection{Sample characteristic}

Table 2: Characteristics of the owner-manager Profile

\begin{tabular}{|c|c|c|c|c|}
\hline $\begin{array}{l}\text { Characteristic of the } \\
\text { owner-manager }\end{array}$ & & Effective & $\begin{array}{l}\% \\
\text { Valid }\end{array}$ & $\begin{array}{l}\% \\
\text { Accrued }\end{array}$ \\
\hline \multirow{4}{*}{$\begin{array}{l}\text { Level of education } \\
\text { the owner-manager }\end{array}$} & Primary & 150 & 83.33 & 83.33 \\
\hline & Secondary & 25 & 13.89 & 97.22 \\
\hline & University & 05 & 2.78 & 100.0 \\
\hline & Total & 180 & 100.0 & \\
\hline \multirow{5}{*}{$\begin{array}{l}\text { Type of training } \\
\text { the owner-manager }\end{array}$} & Management & 39 & 21.67 & 21.67 \\
\hline & Economy & 10 & 05.55 & 27.22 \\
\hline & Law & 03 & 01.67 & 28.89 \\
\hline & Other & 128 & 71.11 & 100.0 \\
\hline & Total & 180 & 100.0 & \\
\hline \multirow{4}{*}{$\begin{array}{l}\text { Geographic origin } \\
\text { the owner-manager }\end{array}$} & Great North & 16 & 08.89 & 08.89 \\
\hline & Grand center & 10 & 05.56 & 14.45 \\
\hline & Grand Oust & 154 & 85.55 & 100.0 \\
\hline & Total & 180 & 100.0 & \\
\hline \multirow{4}{*}{$\begin{array}{l}\text { Owner Managed } \\
\text { Experience }\end{array}$} & Month 05 years & 17 & 09.45 & 09.45 \\
\hline & Between 05 and 10 years & 103 & 57.22 & 66.67 \\
\hline & Over 10 years & 60 & 33.33 & 100.0 \\
\hline & Total & 180 & 100.0 & \\
\hline
\end{tabular}

\section{Source: Authors}

A reading of Table 2 above, one realizes that the profile of the owner-managers of firms in the sample is very revealing. It shows that $83.33 \%$ of owner-managers have a primary level of education, $71.11 \%$ have another training in management, economics or law, $56.55 \%$ were aged between 30 and 40 years , 35.56\% are for supporters of the Catholic church, $85.55 \%$ are citizens of the Greater Oust region and $57.22 \%$ have experience of 5 to 10 years.

\subsection{Model Research}

Access to bank credit in its various possible measures, is the endogenous variable that act other exogenous variables of our estimates. Our goal is to determine the factors or variables that may explain the improvement of access to credit for small family businesses. We built the econometric model below with reference to the work of St-Pierre Cadieux (2011)

model: ACCES AU CREDIT = f(Ins; Typef; Exp; Org $)$

The complete empirical form of the model is:

$$
\text { ACCES AU CREDIT }=\alpha+\beta_{1} \text { Ins }+\beta_{2} \text { Typef }+\beta_{3} \operatorname{Exp}+\beta_{4} \text { Org }+\varepsilon
$$

Access to credit

With $i \in \llbracket 1 ; 180 \rrbracket$ and designates companies

Ins: The level of education of the owner-manager

Typef: Type of training the owner-manager of the family business

Exp:Experience the owner-manager

Org: Origin of the owner-manager of the owner of the family business

$\alpha$ : Constant

$\varepsilon:$ the error term

$\boldsymbol{\beta}_{\boldsymbol{i}}$ : The coefficient is 1 to 4

\subsection{Description of variables}

We have two types of variables: The dependent variable and the explanatory variables.

\subsubsection{Dependent variable}

Access to bank credit is our main endogenous or dependent variable.

- Access to bank credit: We defined this component of the dependent variable in two dimensions. It takes the value 1 if the firm had access to bank credit and 0 otherwise.

2.5.2. Explanatory variables

We have four types of variables are:The level of education of the owner-manager, the type Training the ownermanager, the experience of the owner-manager and the geographical origin of the owner-manager.

- The level of education of the owner-manager : The variable level of education is set to 1 if the ownermanager at a primary level, the value 2 if he has a high level and value 3 if he has a higher level. 
- The type Training the owner-manager: This variable is set to 1 if the owner-manager has followed a management training, the value 2 if it has an economy training, the value 3 if he has legal training and 4 if he has rather a different kind training.

- The experience of the owner-manager: it is the number of previous working years of the owner-manager in a given field. It takes the value 1 if it has less than 5 years of experience, the value 2 if it has between 5 and 10 years of experience and the value 3 if he has more than 10 years experience.

-The origin of the owner-manager: also characteristic of the social network, it corresponds to the situation where the owner-manager belongs to one of the three major regional groups in our country. It takes the value 1 if the owner-manager is native to the Far North region, the value 2 if it is from the deep south and the value 3 if it is from the Great West region.

Table 3: operationalization and variable measures

\begin{tabular}{|c|c|c|c|c|}
\hline \multicolumn{2}{|l|}{ Variables } & \multirow{2}{*}{$\begin{array}{l}\text { Variable } \\
\text { Type } \\
\text { Binary }\end{array}$} & \multirow{2}{*}{$\begin{array}{l}\text { Measures } \\
\text { It takes the value } 1 \text { if the } \\
\text { SMEs access to credit and } \\
0 \text { if not }\end{array}$} & \multirow{2}{*}{$\begin{array}{l}\text { authors } \\
\\
\begin{array}{l}\text { Zambaldi et al. } \\
(2011)\end{array}\end{array}$} \\
\hline Endogenous & $\begin{array}{l}\text { Access to bank credit } \\
\text { Access to credit }\end{array}$ & & & \\
\hline \multirow{4}{*}{ exogenous } & $\begin{array}{l}\text { The educational level of } \\
\text { owner-manager } \\
\text { (Ins) }\end{array}$ & nominal & $\begin{array}{l}1=\text { Primary } \\
2=\text { Secondary } \\
3=\text { Superior }\end{array}$ & Nguena (2012) \\
\hline & $\begin{array}{l}\text { Quality or type of training } \\
\text { owner-manager Family } \\
\text { SMEs (qtf) }\end{array}$ & nominal & $\begin{array}{l}1=\text { Management } \\
2=\text { Economics } \\
3=\text { Right }^{-} \\
4=\text { Other }^{1}\end{array}$ & $\begin{array}{lc}\text { McMahon } & \text { et al. } \\
(1993), & \text { St-Pierre } \\
(2004) & \end{array}$ \\
\hline & $\begin{array}{l}\text { owner of the original- } \\
\text { dirigeant Family SMEs } \\
\text { (Org) }\end{array}$ & nominal & $\begin{array}{l}1=\text { Far North } \\
2=\text { Great South } \\
3=\text { Greater West }\end{array}$ & $\begin{array}{l}\text { Smith and Miner } \\
(1983)\end{array}$ \\
\hline & $\begin{array}{l}\text { The experience of the } \\
\text { owner-manager of the } \\
\text { family business } \\
\text { (Exp) }\end{array}$ & nominal & $\begin{array}{l}1=\text { Less than } 05 \text { years } \\
2=\text { between } 05 \text { and } 10 \\
\text { years } \\
3=\text { More than } 10 \text { years }\end{array}$ & $\begin{array}{lr}\text { Cooper } & (1970), \\
\text { Cooper } & (1973), \\
\text { Koontz } & \text { and } \\
\text { O'Donnell } & (1980)\end{array}$ \\
\hline
\end{tabular}

\section{Source: Authors}

\section{RESULTS ANALYSIS AND DISCUSSION}

In this part, we will initially introduce the Chi-square tests and finally a parameter estimation method by Logistics.

\subsection{The chi-square test of independence}

We present in turn results on tests Chi-Square between the level of education of the owner-manager, the type of training the owner-manager, the age of the owner-manager, the geographical origin of the owner-manager, the religious affiliation of the owner-manager, the experience of owner-manager, the age of SMEs, size and access to bank credit.

3.1.1. Tests of independence chi-square between the level of education of the owner-manager and access to bank credit

The chi-square test the level of education of the owner-manager lets you know if there's a significant relationship between the level of education of the owner-manager and access to bank credit in Cameroonian family SMEs. Table No. 4 below contains information that will shed light on the nature of the relationship that may exist between the dependent variable and the educational level of owner-manager.

Table 4: Independence Tests Chi-Square on the level of education of the owner-manager and access to bank credit

\begin{tabular}{|l|l|l|l|}
\hline & Value & dOF & asymptotic significance (bilateral) \\
\hline Chi-square Pearson & 0.730 & 2 & $0,084^{*}$ \\
Likelihood Ratio & 0.717 & 2 & 0.595 \\
linear combination by linear & 0.525 & 1 & 0.487 \\
Number of valid observations & 180 & & \\
\hline
\end{tabular}

*: Significant at $\mathbf{1 0 \%}$

Source: Authors

The Chi-square test of independence through Table 4 above shows that a degree of freedom for 2 with a

${ }^{1}$ Refers to other courses (Chemistry, Mathematics, Physics, Letter Agriculture, Livestock among others). 
calculated value (0.730), there is significant relationship between the level of education of the owner-manager and access to bank credit in Cameroonian family SMEs in the $10 \%$ threshold. This result corroborates accurately reserves with the work of Nguena (2012), which findsthe low level of education negatively affects the financial situation of the company since employees sometimes the uneducated promoter consider the bank as a place reserved for special people where they can not be considered.

3.1.2. Tests of independence chi-square between the type training the owner-manager and access to bank credit The chi-square test the type of training allows the owner-manager whether there's a significant relationship between the type of owner-manager of training and access to bank credit of Cameroonian family SMEs.

Table 5: test of independence chi-square on the type of training the owner-manager

\begin{tabular}{|l|l|l|l|}
\hline & Value & dOF & \multicolumn{1}{|c|}{$\begin{array}{c}\text { asymptotic significance } \\
\text { (bilateral) }\end{array}$} \\
\hline Chi-square Pearson & 1,618 & 1 & $0.009 * * *$ \\
Likelihood Ratio & 1,584 & 3 & 0.776 \\
linear combination by linear & 1,516 & 1 & 0,120 \\
Number of valid observations & 180 & & \\
\hline
\end{tabular}

\section{: Significant at the $1 \%$}

\section{Source: Authors}

The result of the independence of chi-square test through Table 5 above shows that there is a significant relationship between the type of owner-manager of training and access to bank credit for family SMEs in Cameroon at the $1 \%$, a degree of freedom of 1 and a value of the calculated chi-square 1.618. This result corroborates the results of McMahon and al. (1993), who think that the specific training the owner-manager in a particular area is considered an asset by bankers.

3.1.3. test of independence chi-square between The experience of the owner-manager and access to bank credit The chi-square test on the experience of the owner-manager enable whether there's a significant relationship between the experience of the owner-manager and access to bank credit by the Cameroonian family SMEs.

Table 6: Independence Test Chi-Square onthe experience of the owner-manager

\begin{tabular}{|l|l|l|l|}
\hline & \multicolumn{1}{|c|}{ Value } & \multicolumn{1}{c|}{ dOF } & \multicolumn{1}{c|}{$\begin{array}{c}\text { asymptotic significance } \\
\text { (bilateral) }\end{array}$} \\
\hline Chi-square Pearson & 3,122 & 1 & $0.002 * * *$ \\
Likelihood Ratio & 1,173 & 1 & 0,021 \\
linear combination by linear & 6,241 & 1 & 0.043 \\
Number of valid observations & 180 & & \\
\hline
\end{tabular}

\section{: Significant at the $1 \%$}

\section{Source: Authors}

The results of the chi-square test of independence through Table 6 above shows that there is a significant relationship at the $1 \%$ for a degree of freedom equal to 1 and a value of chi-square calculated 3,122 enter the experience of the owner-manager and access to bank credit by Cameroonian family SMEs. Pending the results of parameter estimation, this result goes in the same direction as the outcome ofKoontz and O'Donnell (1980), indicating that the experience in previous jobs can have an indirect influence on the success of the company.

3.1.4. test of independence chi-square between the geographical origin of the owner-manager and access to bank credit

The chi-square test on the geographical origin of the owner-manager lets you know if there's a significant relationship between the age of the owner-manager and access to bank credit by the Cameroonian family SMEs.

Table 7: Independence Test Chi-Square on the geographical origin of the owner-manager

\begin{tabular}{|l|l|l|l|}
\hline & \multicolumn{1}{|c|}{ Value } & \multicolumn{1}{|c|}{ dOF } & \multicolumn{1}{c|}{$\begin{array}{c}\text { asymptotic significance } \\
\text { (bilateral) }\end{array}$} \\
\hline Chi-square Pearson & 1,213 & 1 & $0.004 * * *$ \\
Likelihood Ratio & 3,126 & 1 & 0.920 \\
linear combination by linear & 4,441 & 1 & 0,039 \\
Number of valid observations & 180 & & \\
\hline
\end{tabular}

\section{${ }^{* * *}$ : Significant at the $1 \%$}

\section{Source: Authors}

The results of the chi-square test of independence through Table 7 above shows that there is a significant relationship at the $1 \%$ for a degree of freedom equal to 1 and a value of chi-square calculated 1,213 enter the geographical origin of the owner-manager and access to bank credit by Cameroonian Family SMEs. Pending the results of parameter estimation, this result corroborates the findings of Wamba (2013), which supports the idea of an influence of the social network on the level of indebtedness of the company. 
3.2. Results of the multivariate analysis explanatory

Since the chi-square test does not specify the direction of the relationship between variables and ignores the interrelationships that may exist between the variables, we have used the logistic regression seems to fill the breach. This parameter estimation is to determine the direction or the sign of relationships between variables and to check if there is a significant linkbetween the level of education of the owner-manager, the type of training the ownermanager, the experience of the owner-manager and the geographical origin of the owner-manager, and access to bank credit. This will allow us to validate or invalidate our research hypotheses. Table No. 8 below shows parameter estimation performed using the following model.

Table 8: Parameter Estimation

$$
\text { ACCES AU CREDIT }=\alpha+\beta_{1} \text { Ins }+\beta_{2} \text { Typef }+\beta_{3} \text { Exp }+\beta_{4} \text { OrgP }+\varepsilon
$$

\begin{tabular}{|c|c|c|c|c|c|c|}
\hline & \multicolumn{6}{|c|}{ Access to bank credit } \\
\hline & $B$ & ES & Wald & $\mathrm{dOF}$ & Sig. & $\operatorname{Exp}(\beta)$ \\
\hline Level of education & $-1,299$ & 0.251 & 6,216 & 1 & $0.026 * *$ & 3,120 \\
\hline Type of training & -0.621 & 0.520 & 2,552 & 1 & $0.008 * * *$ & 2,196 \\
\hline Geographic origin & 3,625 & 0,135 & 6,110 & 1 & $-0.002 * * *$ & 2,325 \\
\hline Experience & 1,257 & 0.241 & 5,214 & 1 & $0.053 * *$ & 9.121 \\
\hline \multirow[t]{2}{*}{ Constant } & -2.161 & 1,334 & 0,770 & 1 & 0.483 & 1,318 \\
\hline & \multicolumn{6}{|c|}{$\begin{array}{l}\text { - R-square }=0.856 \text { Nagelkerke } \\
\text { - R-both Cox } \& \text { Snell }=0.721 \\
-2 \log \text { likelihood }=48.841 \\
\text { - Value of chi-square }=6.535 \\
-\mathrm{P}=0.004 * * *\end{array}$} \\
\hline
\end{tabular}

\section{: Significant at the $1 \%$ level ** Significant at $5 \%$ *: Significant at $10 \%$}

\section{Source: Authors}

A reading of Table 8 above, it may be noted that this model reveals, as regards the variable representing unspecified factor (constant), a negative value of $\alpha=$ non significant $-2,161$ et. Moreover, the statistical chi-square evidencing the model specification that is significant at the $1 \%$. It is observed that three variables are significant at the $5 \%$ threshold, a significant variable at the $10 \%$ threshold and two significant at the $1 \%$ level. It is concluded by Nagelkerke $\mathrm{r} 2$ thatthe level of education of the owner-manager, the quality of training of the owner-manager, the age of the owner-manager, the religious affiliation of the owner-manager, the geographical origin of the ownermanager and owner experience -dirigeant explain $85.6 \%$ access to bank credit for family businesses Cameroon sample.

3.2.1. Theeducation of the owner-manager

A reading of Table 8 above, we observe that there is a significant and negative relationship between the $5 \%$ threshold the level of education of the owner-manager and access to bank credit with a value $\beta=-1.299$. It does not conform to the sign provided by the estimation model and means that the probability of having access to bank credit decreases as owner-managers are less educated. This result is those work Nguena (2012), which argues that the low level of education negatively affects the financial situation of the company when employees and sometimes the uneducated promoter consider the bank as a place reserved for special people where they can not be considered. The negative influence $(\beta=-1.299)$ of education on access to bank credit here can be explained by the fact that the Multivariate analysis takes into account all variables without separating them, but especially by the very low level of small business owners in our educational context. Because the INS / EGM-2 (2018) says that more than half (51\%) of companies are created by developers with the CEP / CPCE / FLSC (including, 20\% are without a diploma); $24 \%$ do not hold the BEPC; $17 \%$ with a degree of the second cycle of secondary education and $7 \%$ with a graduate education superior. Thus, according to still INS / REG (2018), Cameroonian entrepreneurs therefore show a low level instruction, reflecting the fact that it is individuals who have failed in the formal education system who engage in entrepreneurship. This result supports the hypothesis H1 which states that most owner-manager has studied, the more it has access to bank credit.

3.2.2. The type of training the owner-manager

On reading the same Table 8 , it is observed that the type of training has a significant and negative impact on access to bank credit at $1 \%$ level with a value of $\beta=-0.621$, which is not consistent with predictions of the estimation model and means that the probability of having access to bank credit decreases depending on the type of training the owner-manager other than management training. This result is consistent with the findings of McMahon et al. (1993), who found thatthe leader who have received training in management is able to analyze and interpret financial statements, which according to bankers is positive because it allows it to reduce the financial risk and those St-Pierre (2004), which think knowledge of the leader of the SME is a source of performance and in its 
research that leader with knowledge management is able to perform financial controls and reducing the company's bankruptcy risk.

Like education, the negative influence $(\beta=-0.621)$ the type of training on access to bank credit here can be explained by the very low level of small business owners in our educational context wherein more than half $(51 \%)$ of companies are created by developers with the CEP / CPCE / FLSC(INS / RGE-2, 2018). This confirms the hypothesis $\mathrm{H}_{2}$ which states that the type of training the owner-manager significantly influences access to bank credit.

3.2.3. The geographical origin of the owner-manager

A reading of the same table 8 shows that, the type of training has a significant and positive influence on access to bank credit at the $1 \%$ threshold with a value of $\beta=3.625$, which is in line with the result obtained. by the chisquare test and predictions of the estimation model and means that the likelihood of having access to bank credit increases with the type of owner-manager training. Like the religious affiliation, this result corroborates with the results of the works of Granovetter (1973), Baker (1990) and Bourdieu (1980), who think that the environment of the social relations of the leader determines the obtaining of bank credit. This confirms the hypothesis $\mathrm{H}_{4} \mathrm{which}$ states that the origin of the owner-manager exerts a significant influence on access to bank credit.

3.2.4. The owner-manager experience

Reading the same table 8 , we observe that, the type of training significantly and positively influences access to bank credit at the $5 \%$ threshold with a value of $\beta=1.257$, which is in line with the predictions of the model of estimate and means that the likelihood of having access to bank credit increases with the experience of the ownermanager acquired in those previous years of work in a given field. This result corroborates with the results of the work of Koontz and O'Donnell, (1980), who found that the experience accumulated in previous jobs can have an indirect influence on the success of the enterprise; and those of Teyssier (2010), which finds that the more experienced the manager, the more he sets up systems to protect the company against the risks of too much financial pressure. This then confirms the hypothesis $\mathrm{H}_{3}$ which states that the more the owner-manager is experienced, the more he has access to bank credit.

\section{Conclusion}

The purpose of this research was to verify the effect of owner-manager education, the type of owner-manager training, the geographic origin of the owner-manager, the owner-manager experience with the owner-manager. access to bank credit for Cameroonian family SMEs.

It was found in this research, from the sample that the owner-managers are, at $83.33 \%$ less educated and have a primary level of education, $71.11 \%$ have a training other than management, economy or law, $85.55 \%$ are nationals of the Western Great region and 57.22\% who have experience between 5 and 10 years.

Based on chi-square tests and logistic regression, we found that owner-manager education and the type of ownermanager training have a significant and negative influence on access to bank credit of Cameroonian family SMEs. This allows us to think that these two variables are a real problem for access to bank credit for Cameroonian family SMEs. On the other hand, the owner-manager's experience and the geographical origin of the owner-manager exert a significant and positive influence on access to bank credit for family SMEs in Cameroon.

Nevertheless, there is still a cry for family-owned SMEs, as the problem of access to bank credit could perhaps be absorbed if SME owners made an effort to improve the quality of other factors that could facilitate access. To bank credit such as:

- Recruit the highly educated leaders who will understand that the bank is open to all and the only place able to ensure adequate funding;

- Recruit executives who have completed management training who will be able to analyze the financial situation of the company and detect risks;

- Recruit managers with more than 05 years of experience in the field of activity able to develop strategies to protect the company against financial risks and pressures.

- Search and approach bank branches that have a member of the same geographical origin.

These recommendations reflect the reality of the context of Cameroonian family SMEs and can, as far as possible, be justified by the fact that $85.55 \%$ of the owner-managers of the SMEs in the sample come from the same geographical area, $57,22 \%$ who have more than 05 years of experience.

\section{REFERENCES BIBLIOGRAPHIQUES}

Ananga, O. A. et Makani, S. R., (2018), « Quels déterminants pour les politiques comptables dans les PME Camerounaises ? », Revue du Contrôle de la Comptabilité et de l'Audit, Numéro 4, Mars 2018, p. 108-135.

Aterido, R., Hallward-Driemeier, M., Pagés, C., (2007), " Investment Climate and Employment Growth: The Impact of Access to Finance, Corruption and Regulations Across Firms », Inter-American Development Bank, Institute for the study of labor (IZA) (3138).

Ayyagari, M., Asli, D. et Vojislav, M., (2006), « How Important Are Financing Constraints? the Role of Finance 
in the Business Environment », Research Working papers, 1(1), 1-59.

Ayyagari, M., Asli, D. et Vojislav, M., (2008), « How Important Are Financing Constraints? the Role of Finance in the Business Environment », The World Bank Economic Review, 22 (3), 483-516.

Baker, W., (1990), « Market Network and Corporate Behavior », American Journal of Sociology, N 96, pp.589625.

Banque Mondiale. (2004). World development report 2005. A better investment Climate for everyone. Washington DC: Banque Mondiale.

Beck, T., Demirguc-Kunt, A. et Levine, R., (2004), "Law and Firms’ Access to Finance » The world Bank (3194).

Beck, T., Demirgüç-Kunt, A. et Maksimovic, V., (2005), « Financial and Legal Constraints to Growth: Does Firm Size Matter? ». The Journal of Finance, 60(1), 137-177.

Beck, T., Demirgüç-Kunt, A., Laeven, L. et Maksimovic, V., (2006), « The Determinants of Financing Obstacles $»$, Journal of International Money and Finance, 25(6), 932-952.

Bekolo-Ebé, B., (1992), « Dynamique Nouvelle de Financement et Sortie de Crise au Cameroun », Mondes en Développement.

Bekole-Ebé, B., (2002), « Intermédiation financière et financement du développement en Afrique », Presse universitaires de Yaoundé.

Bigsten, A., Collier, P., Dercon, S., Fafchamps, M., Gauthier, B., Gunning, J. W.,et Zeufack, A., (2003), « Credit Constraints in Manufacturing Enterprises in Africa », Journal of African Economies, 12(1), 104-125.

Charreaux, G., Pitol- Charreaux, G., (1997), Belin, J-P., (1989), « Image et réalités du conseil d'administration », Revue Française de Gestion, juin-juillet-août, P. 49- 61.

Coleman, J. S., 1988, « Social Capital in the Creation of Human Capital », American Journal of Sociology, Vol. 94, Supplement : Organizations and Institutions : Sociological and Economic Approaches to the Analysis of the Social Structure, p. 95-120.

Cooper, A.C., (1970), « Entrepreneural Environnement », Industrial Research, September.

Cooper, A.C., (1973), « Technical Entrepreneurship: What do we Know? », Reaserch and Développement Management, 3, February.

Colot, O., Croquet, M., et Pozniak, L., (2010), « Déterminants des choix de financement et profils de PME », Journal of Small Business \& Entrepreneurship, 23(1), pp. 97-115.

Combs, J. G., Penney, C. R., Crook, T. R., \& Short, J. C., (2010), « The Impact of Family Representation on CEO Compensation », Entrepreneurship Theory \& Practice, 34(6), p.1125-1144.

DeSerres, A., Kobayakawa, S., Sløk, T. et Vartia, L., (2006), " Réglementation des systèmes financiers et croissance économique dans les pays de l'OCDE ». Revue économique de l'OCDE, (43), 89-131.

Evrard, Y., Pras B. et Roux, E., (2000), Market : Etude et Recherche en Marketing, Paris, Dunod.

Feudjo, J. R. \& Tchankam, J. P., (2012), « Les déterminants de la structure financière : comment expliquer le paradoxe de l'insolvabilité et de l'endettement des PMI au Cameroun ? », Revue Internationale PME, Vol. 2.

Fonds Monétaire International, (2006a), Central African Economic and Monetary Community : Financial System Stability Assessment, including Reports on the Observance of Standards and Codes on the following topics : Monetary and Financial Policy Transparency, and Banking Supervision, IMF Country Report n ${ }^{\circ} 06 / 321$, FMI.

Fouda, O., (2009), « La surliquidité des banques en zone franc: comment expliquer le paradoxe de la CEMAC?», Revue Africaine de l'Intégration, 3(2), p. 43-62.

Granovetter, M., (1973), « The Strengh of Weak Ties », American Journal of Sociology, Vol. 78, N 6, p. 1360-1 380.

Handler, W. C., (1989), Managing the Familly firm Succession Process : The Next Generation Family Member's Experience, Graduate School of Management, Boston, Universituy.

Hollander, B. S., Elman, N. S., (1988), « Family-Owned Businesses: an Emerging Field Inquiry, Family Business Review, Vol.1, No.2, P. 145-163.

INS/RGE, (2009), Institut Nationale de la Statistique/Recensement général des entreprises (RGE-1), Rapports thématiques, partie I: Environnement des affaires et compétitivité des entreprises camerounaises, 52 pages.

INS/RGE, (2018), Institut Nationale de la Statistique/Recensement général des entreprises

2016 (RGE-2), rapport préliminaire des principaux résultats, 40 pages.

Jensen, M. C., Meckling, W., (1976), « The Theory of the Firm: Managerial Behavior, Agency Cost and Ownership Structure », Journal of Financial Economics, 3, p.305-360.

Karpik, L., (1989), « L’économie de la qualité », Revue française de sociologie, 30, 2, pp. 187-210.

Kauffmann, C., (2005), « Le financement des PME en Afrique », Repères n 7, OCDE.

King, R. G. et Levine, R., (1993), «Financial Intermediation and Economic Development »,

Capital markets and financial intermediation,156-189.

Koontz, H., O'Donnel, C., (1980), Management, principes et méthodes de gestion, Montréal, Mac Graw-Hill 1980. Kut, C., et Smolarski, J., (2011), « The Impact of Venture Capital Financing Method on SME

Performance and Internationalization », International Entrepreneurship and Management Journal, 7(1), p. 39-55. 
Lehmann, E. \& Neuberger, D., (2001), « Do Lending Relationship Matter ? Evidence from Bank Survey Data in Germany », Journal of Economic Behavior and Organization, Vol. 45, p. 339-359.

Levratto, N., (1990), « Le fmancement des PME par les banques contraintes des firmes et limites », Revue internationale PME, 3(2), p. 193-213.

Libecap, G., (1989), « Contracting for Property Rights », New York, Cambridge University Press.

McMahon, R. G. P., Holmes, S., Hutchinson P. J. et Forsaith D. M., (1993), Small Enterprise Financial Management, Theory \& Practice, Sydney Fort Worth London Orlando Toronto, Harcourt Brace.

Miloudi, A. et Benkraiem, R., (2014), « L'internationalisation des PME affecte-t-elle l'accès au financement bancaire? », Management International, 18(2), p. 70-79.

MINPMEESA., (2009), Etude sur la formulation du plan directeur (M/P) pour le développement des Petites et Moyennes Entreprises en République du Cameroun, Agence

Japonaise de Cooperation Internationale. Unico International Corporation.

Modigliani, F. \& Miller, M., (1958), « The Cost of Capital, Corporate Finance and the Theory of Investment », American Economic Review, Vol. 58, ํ3, p. 261-297.

Nahapiet, J. and Ghoshal, S., (1998), « Social Capital, Intellectual Capital, and the Organizational Advantage », Academy of Management Review, Vol. 23, p. 242-266.

Napier, C., (2006), "Accounts of Change: 30 Years of Historical Accounting Research », Accounting, Organizations and Society, 31 (4-5), p. 445-507.

Ndjanyou, L., 2001), «Risque, incertitude, et financement bancaire de la P.M.E. camerounaise: l'exigence d'une analyse spécifique du risque », Center for Economic Research on Africa, School of Business, Montclair State University, Upper Montclair, New Jersey, 07043, 27p.

Ndeffo, N. L. et Ningaye, (2007), « Réformes financières et rentabilité du système bancaire des Etats de la CEMAC », African Economic Conference, Opportunities and challenges of

development for Africa in the global area.

Nguena C. L., (2012), « Le financement des pme au Cameroun dans un contexte de crise financière ",Munich Personal Repec Archive, 35 pages.

Nkakleu, R., (2003), «L'identité organisationnelle et création du capital social : la tontine d'entreprise comme facteur déclenchant le contexte africain », Actes des XVIe journées nationales des IAE, p. 1-22, Paris les 10, 11 et 12 septembre.

Nkurunziza, J. D., (2010), "The Effect of Credit on Growth and Convergence of Firm Size in Kenyan Manufacturing », The Journal of International Trade \& Economic Development, 19(3), 465-494.

Ojah, K., Gwatidzo, T. et Kaniki, S., (2010), « Legal Environment, Finance Channels and Investment: The East African Example », The Journal of Development Studies, 46(4), 724- 744.

Robidoux, J., (1978), Les crises administratives dans les PME en croissance, Chicoutimi, Gaétan Morin éditeur, 1978.

Shleifer, A. et Vishny, R., (1997), « A Survey of Corporate Governance », Journal of Finance, no 52, 737-784.

Smith, N. R. Et Miner, J. B., (1983), « Type of Entrepreneur, Type of Firm, and Managerial Motivation: Implications for Organizational Life Cycle Theory », Strategic Management Journal, Vol.4, p. 325-340.

St-Pierre, J., (2004), « La gestion du risque : Comment améliorer le financement des PME et faciliter leur développement », Presses de l'Universite du Quebec Canada, Quebec.

St-Pierre, J. et Cadieux, L., (2011), « La conception de la performance : quels liens avec le profil entrepreneurial des propriétaires dirigeants de pme ? », Revue de l'Entrepreneuriat, No1, Vol. 10, p. 33-52.

Susbaurer, J. C., (1972), « The Technical Entrepreneurship Process in Austin, Texas ». Technical Entrepeneurship, A sympoisium eds A.C.1972.

Tagiruri, R, et Davis, J. A., (1982), Bivalent Attributes of the Family Firm, Santa Barbara, CA, Owner Management Business Institute.

Taka, D., (2016), « Les déterminants de l'accès au financement bancaire par les Petites et

Moyennes Entreprises: cas du Cameroun », Revue d'Economie Théorique et Appliquée,

Volume 6, Numéro 1 - Juin 2016, p. 77- 96

Teyssier, C., (2010), «L'influence des caractéristiques du dirigeant et de l'équipe dirigeante sur le management financier de la PME en hyper-croissance : une approche par études de cas », Xe Congrès International francophone en Entrepreneuriat et PME (CIFEPME).

Toulouse, J. M., (1979), « L'entrepeneurship au Québec », Les presses H.E.C., Fides.

Wamba, H., (2013), « Capital social et accès des PME africaines au crédit bancaire: le cas du

Cameroun », La revue des sciences de gestion, 48(259-260), p. 53-68.

Wanda, R., (2007), « Risques, comportements bancaires et déterminants de la surliquidité »,

Revue des Sciences de Gestion, (228), pp. 93-102.

Zambaldi, F., Aranha, F., Lopez, H. et Politi, R., (2011), « Credit Granting to Small Firms: a Brazilian Case », Journal of Business Research, 64(3), 309-315. 